\title{
The Chimalapas Region, Oaxaca, Mexico: a high-priority region for bird conservation in Mesoamerica
}

\author{
A. TOWNSEND PETERSON, ADOLFO G. NAVARRO-SIGÜENZA, \\ BLANCA E. HERNÁNDEZ-BAÑOS, GRISELDA ESCALONA-SEGURA, \\ FANNY REBÓN-GALLARDO, EMIR RODRÍGUEZ-AYALA, \\ ELSA M. FIGUEROA-ESQUIVEL and LEONARDO CABRERA-GARCÍA
}

\begin{abstract}
Summary
The Chimalapas region, in eastern Oaxaca, Mexico, holds lowland rainforests, tropical dry forests, and cloud forests typical of the Neotropics, as well as montane pine and pine-oak forests more typical of the Nearctic. Totaling more than $600,000 \mathrm{ha}$, much of the region is forested, and in a good state of preservation. The Chimalapas avifauna is by far the most diverse for any region of comparable size in the country, totalling at least 464 species in the region as a whole (with more than 300 species in the lowland rainforest) representing $44 \%$ of the bird species known from Mexico. Within the region, the humid Atlantic lowlands hold 317 species, the montane regions 113 species, and the southern dry forested lowlands 216 species. Important species present in the region include Harpy Eagle Harpia harpyja and several other large eagles, Black Penelopina nigra and probably Horned Oreophasis derbianus Guans, Scarlet Macaw Ara macao, Cinnamon-tailed Sparrow Aimophila sumichrasti, Rose-bellied Bunting Passerina rositae, and Resplendent Quetzal Pharomachrus mocinno. The area holds immense lowland rainforests and cloud forests that rank among the largest and best preserved in all of Mesoamerica, including a complete lowland-to-highland continuum, with entire watersheds preserved more or less intact.
\end{abstract}

\section{Resumen}

La región de Los Chimalapas, en el este del estado de Oaxaca, México, contiene selvas tropicales húmedas, selvas tropicales secas y bosques mesófilos de montaña típicos del Neotrópico, además de bosques montanos de pino y pino-encino más típicos del Neártico. Con un total de más de 600,000 ha, gran parte de la región está cubierta por bosque en buen estado de conservación. La avifauna de los Chimalapas, que está compuesta por más de 300 especies en la selva y al menos 458 especies en la región en su totalidad, es por mucho la más diversa de cualquier región de tamaño comparable en el país, representando el $44 \%$ de las especies conocidas para México. Dentro de la región, las tierras bajas del Atlántico contienen al menos 314 especies, las regiones montanas 110 especies y los bosques secos tropicales 211 especies. Especies importantes presentes en la región incluyen al águila arpía Harpia harpyja y otras águilas grandes, el pajuil Penelopina nigra y probablemente el pavón Oreophasis derbianus, la guacamaya roja Ara macao, el zacatonero itsmeño Aimophila sumichrasti, el colorín azulrosa Passerina 
rositae y el quetzal Pharomachrus mocinno. El área mantiene inmensas extensiones de selva tropical y bosque mesófilo de montaña que están entre los más grandes y mejor preservados en Mesoamérica, incluyendo un continuo completo de tierras altas a bajas, con cuencas enteras conservadas de manera más o menos intactas.

\section{Introduction}

Mexico is famous as a "megadiverse country", lying at the conjunction of two great biogeographical realms, the Nearctic and the Neotropics (Wilson 1988). Its biological richness stems in part from admixture of faunas from the two regions, and in part from the rich store of endemic forms in the country (Ramamoorthy et al. 1993). Hence, Mexican biodiversity is a perpetual contrast of elements that are uniquely Mexican with elements shared with countries to the north or south.

The conjunction of the Nearctic and Neotropics is nowhere more notable than in the state of Oaxaca, at the southern extreme of many Nearctic habitat distributions (Escalante-Pliego et al. 1993). Much more complex than a simple two-region meeting, Oaxaca holds montane and lowland habitats, elements from both the Pacific and Atlantic slopes of Mexico, as well as dry interior valleys, making for a geographical diversity unparalleled in the country. The biological diversity of Oaxaca is not approached even by other countries in Mesoamerica (Binford 1989, Ramamoorthy et al. 1993).

The Chimalapas region, made up of the municipios of Santa María Chimalapa and San Miguel Chimalapa, occupies the state's eastern arm, bordering Veracruz and Chiapas (Figure 1). The region holds lowland rainforests, tropical dry forests and cloud forests typical of the Neotropics, as well as montane pine and pine-oak forests more typical of the Nearctic. The region contains much of the watershed of the Río Corte, as well as the upper reaches of the Uxpanapa, Ostuta, and Oaxaca rivers. Totalling more than $600,000 \mathrm{ha}$, much of the region is forested, and in a good state of preservation.

Although Oaxaca has been a mecca for naturalists and systematic biologists for more than 150 years, biological studies in the Chimalapas have been few (Binford 1989). Aside from occasional collecting by W. B. Richardson at the end of the nineteenth century (specimens principally at the British Museum), and intensive collecting in the mid-twentieth century near Sarabia and Matias Romero in the Atlantic lowlands of the Isthmus of Tehuantepec (W. J. Schaldach, A. R. Phillips), at the western fringe of the Chimalapas region, attention paid to the region's extensive humid tropical lowlands has been nil. In the southern portion of the region, the dry tropical forests have seen but minimal scientific attention.

The only sector of the Chimalapas that has seen a reasonable amount of study is the montane area at the south-eastern extreme of the region (e.g. W. Rook, J. S. Rowley, L. C. Binford). Amphibians, reptiles, birds and mammals were studied on Cerro Baúl and nearby summits in 1940-1970 (Rowley 1984, Binford 1989). Recent herpetological studies there have produced numerous forms new to science, totalling at least eight reptile and amphibian species endemic to the south-eastern portion of the Chimalapas (A. Nieto Montes de Oca pers. comm.). 


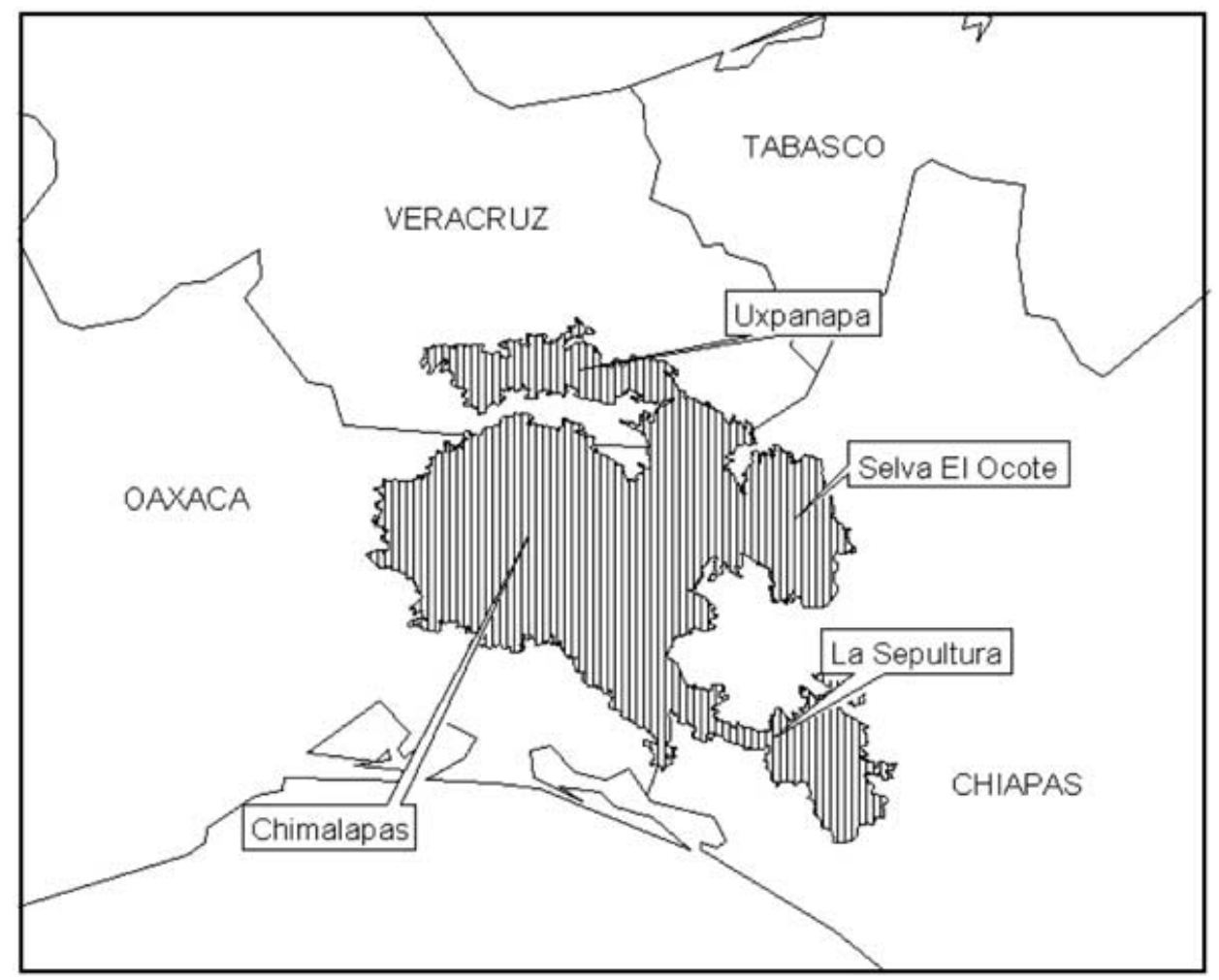

Figure 1. Geographical location of the Chimalapas region, Mexico, and related areas (modified from Maderas del Pueblo 1995, and Arizmendi and Márquez 2000). Shaded areas constitute a priority region called the Selva Zoque, including the Chimalapas and adjacent tropical areas in Chiapas (La Seputura, El Ocote) and Veracruz (Uxpanapa) proposed in Arriaga-Cabrera et al. (2000).

Nevertheless, these studies were largely restricted to the isolated massif Cerro Baúl, much of which has since been burned or logged. Other major montane areas, including nearby Cerro Salomón, Cerro Guayabitos, Sierra Atravesada (especially Cerro Azul, reaching 2,250 m), Sierra de Tres Picos and Sierra Espinazo del Diablo remain all but unstudied by zoologists. The fauna of the heart of the Chimalapas, including its vast rainforests, have seen little or no study.

The unknown nature of the Chimalapas fauna can be best summarized via its treatment in a recent summary of the birds of Oaxaca (Binford 1989): the montane portions were termed the "Sierra Madre de Chiapas," a designation that would be worse than unacceptable to many of the region's inhabitants! Such early workers little appreciated the great nucleus of intact habitats that the region holds. As a result, in 1991-1997, a group of zoologists and botanists from the Universidad Nacional Autónoma de México, University of Kansas, Universidad de Puebla, and other institutions began a multidisciplinary effort to initiate a catalogue of the animal diversity of the region. Results presented herein, which focus on birds, are a first effort to analyse this new information. 


\section{Methods}

The Chimalapas lie in the easternmost corner of Oaxaca (Figure 1), at the shared border of Oaxaca, Veracruz and Chiapas. With Chajul (Chiapas) and Calakmul (Campeche) they rank among the largest pristine tropical regions of Mexico, holding an impressive number of vegetation types, including cloud forest, tropical rainforest, semi-deciduous tropical forest, humid pine-oak forest, and deciduous tropical forest (Binford 1989, Wendt 1989, 1993; Figure 2). The region had its geological origins in the Upper Cretaceous and the Cenozoic, and holds elevations from 100 to $2,700 \mathrm{~m}$. Mean annual temperatures range from 12 to $23^{\circ} \mathrm{C}$, and mean annual precipitation is generally above $1,500 \mathrm{~mm}$.

Data regarding animal distributions in the Chimalapas were drawn from two principal sources. First, data were obtained in intensive field studies at two sites in the northern portion of the region, both in lowland rainforest: San Isidro La Gringa and Chalchijapa during eight monthly visits of 15 days in 1995. Additional records were gathered in fieldwork by the authors in 1991-1995, and by Figueroa-Esquivel in 1997, including detailed inventories at several additional sites in the region: Sierra Espinazo del Diablo, Santa María Chimalapa, San Miguel Chimalapa and the mountains above Benito Juárez (Cerro Guayabitos and Cerro Salomón).

Second, additional information was available from the database in preparation as the Atlas of the Distribution of the Birds of Mexico, representing more than 300,000 specimen records from Mexico drawn from 43 scientific collections in North America and Europe (Peterson et al. 1998b). For Oaxaca east of Matias

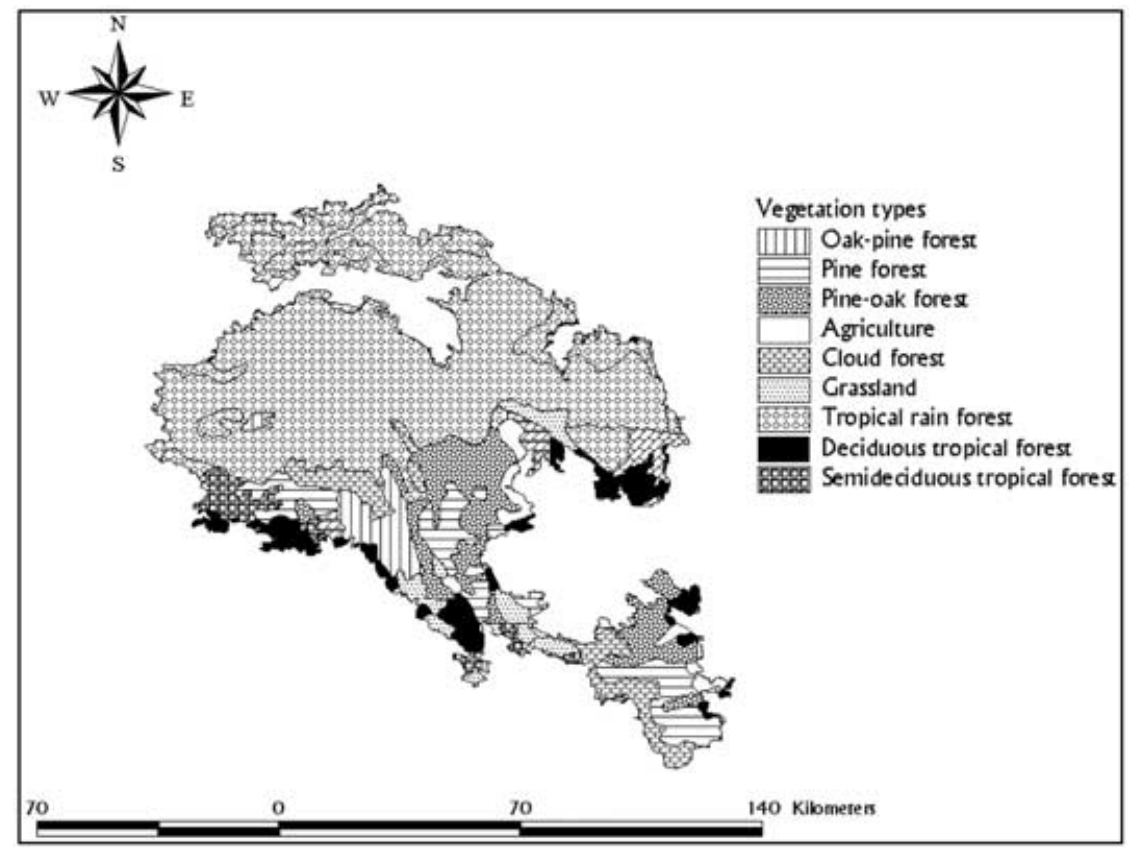

Figure 2. Vegetation types in the Selva Zoque priority region of the Chimalapas, Mexico. Data from http://www.conabio.gob.mx. 
Romero, more than 11 ,000 specimen records from 599 localities were available, although some of these sites were from the Pacific lowlands south of the Chimalapas.

\section{Results}

Species accounts

Various species detected in our inventories or in the specimen record are either listed under some category of international conservation concern (BirdLife International 2000) or are species that are sufficiently rare or little known as to merit further comment regarding the evidence documenting their presence in the Chimalapas. Here, we summarize the documentation available to us either in the form of historical information or as new records that we have accumulated in the course of our studies in the region. In a few cases, documentation is less than satisfactory, which more than anything reflects the poor state of knowledge of the fauna of the Chimalapas and the dire need for further studies.

King Vulture Sarcoramphus papa

Nine specimens collected 1948-1962 (WFVZ 3897, 4351, 8781-3; LSUMZ 43124, 45563; UAZ 8700; MLZ 48902) document the presence of this species both at the north-western fringe (Río Sarabia) and along the southern fringe (Rancho Santa Efigenia, Rancho Sol y Luna, Tapanatepec, Rancho San Vicente) of the Chimalapas region. Our recent surveys documented this species at La Gringa in 1995.

\section{Muscovy Duck Cairina moschata}

Populations of this species were recorded at La Gringa and Chalchijapa in 1995, far from any human presence, suggesting that they are indeed wild populations.

\section{Solitary Eagle Harpyhaliaetus solitarius}

One specimen (BELL 12488) documents the presence of this species at three miles NNE of Tapanatepec. This species was observed 18 times at Benito Juárez, Chalchijapa and La Gringa in 1995 and 1997.

\section{Harpy Eagle Harpia harpyja}

Three specimens document this Near Threatened species in the region of the Chimalapas: WFVZ 10471 (Veracruz, 50 miles up the Río Coatzacoalcos from junction with Río Jaltepec), KU 24802 (Oaxaca, 38 km SE of Jesús Carranza), and IBUNAM Pooo463 (Oaxaca, Rincón Antonio). These specimens constitute the only known records of Harpy Eagle for the state (Escalante-Pliego and Peterson 1994). A nest in a large ceiba near Chalchijapa seen by AGNS was apparently inhabited by a pair of this species in 1994 .

Black-and-white Hawk-Eagle Spizastur melanoleucus

Two specimens document the presence of this species at the south-western peri- 
phery of the Chimalapas, at Cerro Baúl and at Rancho Sol y Luna in 1966-1967 (WFVZ 16584, 19250). No recent records.

Black Hawk-Eagle Spizaetus tyrannus

No specimens exist from the region. However, observations at close range by ATP in 1991 place this species both at Chalchijapa and along the Uxpanapa Road in southernmost Veracruz, and FRG and LCG at La Gringa in 1995.

Ornate Hawk-Eagle Spizaetus ornatus

Five specimens (WFVZ 12409-10, 19228, 12694; KU 103069) place this species both along the south-western (Rancho Vicente, Rancho Enrique) and the northwestern fringe ( 13 miles up the Río Chalchijapa from its union with the Río Coatzacoalcos) of the regions. Recent sight records place this species at La Gringa and Chalchijapa in 1995.

Highland Guan Penelopina nigra

Series totalling 42 specimens (1948-1966) document the presence of this Near Threatened species at numerous localities in the south-western portion of the Chimalapas. More recently, numerous sight records and one specimen (MZFC 13444) place this species abundantly in the mountains near Benito Juárez (Cerro Salomón, Cerro Guayabitos).

Horned Guan Oreophasis derbianus

No specimen records or recent sightings of this Endangered species. However, Dr Jesús Estudillo (pers. comm.) indicated the existence of populations in the region, but without details of localities.

Great Curassow Crax rubra

Numerous specimens (WFVZ, KU, LACM) and sightings place this species throughout the region, at sites including Rancho Vicente, Palomares, La Gringa, Chalchijapa. Recent specimens (MZFC 14116, 14118-9) are from Chalchijapa.

Scarlet Macaw Ara macao

Two specimens place this species in the Chimalapas region: WFVZ 5056 from 16 miles S of Matias Romero, and MLZ 47606 from Rancho Santa Efigenia. Although our survey teams made no sightings, local residents near La Gringa described without prompting this unmistakable species as occurring at least seasonally.

Yellow-headed Parrot Amazona oratrix

Two records (BMUK 893.1.30.332 from Río Grande, Binford 1989 mentions a record from Petapa) are the only documentation of this Endangered species in the Chimalapas

Yellow-naped Parrot Amazona auropalliata

One specimen (MLZ 45517) places this species at five miles W of Zanatepec. 
Black-and-white Owl Ciccaba nigrolineata

Nine specimens (MLZ 47384; AMNH 776282; WFVZ 4708-9, 4679, 10893, 1201920, 16651) place this species at Rancho Sol y Luna, and 18-24 miles N of Matias Romero in 1948-1965. One recent sight record places this species at Chalchijapa in 1991.

Long-tailed Saberwing Campylopterus excellens

Numerous recent specimens (MZFC uncat.) document the presence of this Near Threatened species along the northern fringe of the Chimalapas region, particularly at La Gringa. These series are particularly important because they document sympatry with $C$. curvipennis (MZFC uncat.), confirming the biological species status of these two forms (Rebón Gallardo unpubl. data), and extending the known range of $C$. excellens somewhat southward.

Resplendent Quetzal Pharomachrus mocinno

Seven specimens (WFVZ 12442-8) place this Near Threatened species in the Sierra Reten in 1964. This species was observed once in the Sierra Espinazo del Diablo in 1991, and was found to be abundant in the mountains above Benito Juárez (Cerro Salomón, Cerro Guayabitos) in 1991 and 1997.

\section{Keel-billed Motmot Electron carinatum}

Three specimens (KU 29174, AMNH and MNHNP, neither with catalogue number) place this Vulnerable species at $30 \mathrm{~km}$ SSE of Jesús Carranza, Tolosa, and Santa María Chimalapa, Oaxaca; the MNHNP specimen dates from 1952. The only recent record of this species in all of Mexico was from La Gringa in 1991 (Miller and Miller 1996).

\section{Lovely Cotinga Cotinga amabilis}

Two specimens (WFVZ 27064, 27 km ENE Piedra Blanca, 1962; BMUK 99.5.1.544, Chimalapa, Tehuantepec, 1890) place this species in the Chimalapas.

Nava's Wren Hylorchilus navai

This Vulnerable species is not documented from the Chimalapas region, and indeed is not likely to occur in the heart of the region, for lack of the karstic soils and geology that are so important to it. However, it is known in the Uxpanapa region that touches the northern fringe of the Chimalapas (Atkinson et al. 1993).

Rose-bellied Bunting Passerina rositae

Twenty-eight specimens (WFVZ, MCZ, DMNH, BMUK) document the presence of this Near Threatened species at two localities along the southern fringe of the Chimalapas region ( $11 \mathrm{mi} \mathrm{N}$ Tapanatepec, Rancho Sol y Luna, Rancho Cacoprieto) (1899-1966). Although no new records supplement these, little field time was spent in appropriate habitats.

Cinnamon-tailed Sparrow Aimophila sumichrasti

This Near Threatened species is endemic to the Isthmus of Tehuantepec, includ- 
ing areas along the southern fringe of the Chimalapas (e.g. Santa Efigenia, Santo Domingo Petapa, La Ventosa, 12 miles NE of Juchitán) (Binford 1989).

\section{Species lists}

The avifauna of the Chimalapas is better documented than for any other animal group. The only other biological inventory that approaches completeness is that for forest trees (Wendt 1989). In all, at least 464 bird species are known from the region as a whole (Appendix), representing $44 \%$ of the species known to occur in Mexico (Escalante-Pliego et al. 1993, A.O.U. 1998). Dividing the region into three sectors, the humid Atlantic lowlands are known to hold 317 species, the montane portion 113 species (Hernández-Baños et al. 1995), and the southern dry forested lowlands 216 species.

During the present fieldwork, a total of 299 species were recorded in the region, and a voucher collection of 570 specimens of 163 species were obtained and deposited in the Museo de Zoología (MZFC) and the University of Kansas (KU). In addition, we amassed many hundreds of visual records and observations. Highlights of the bird list include the only known records of Harpy Eagle for the state (Escalante-Pliego and Peterson 1994), records of three other large eagles (Solitary Eagle, Ornate Hawk-Eagle, and Black Hawk-Eagle), the only recent record of Keel-billed Motmot from Mexico (record by ATP) (Miller and Miller 1996) and populations of Scarlet Macaw.

In montane areas, ample populations of the Near Threatened Resplendent Quetzal and Highland Guan were present, and undocumented reports (J. Estudillo pers. comm.) place the Near Threatened Horned Guan there as well; these species all make the region a priority for conservation action, as viable populations of these species may not exist in more than a handful of localities in the world (BirdLife International 200o). The Pacific slope portion of the Chimalapas is likely to hold the only long-term viable populations of the range-restricted and Near-threatened Cinnamon-tailed Sparrow and Rose-bellied Bunting, both of which are narrowly endemic to the dry lowlands of the Pacific side of the Isthmus of Tehuantepec.

\section{Comparisons}

Compared with other sites in southern Mexico and northern Central America, the Chimalapas presents a rich avifauna across an entire lowland-to-highland spectrum. A first countrywide exploration (Escalante-Pliego et al. 1993, Peterson et al. 1993, Hernández-Baños et al. 1995, Peterson et al. 1998a, Peterson and Navarro-Sigüenza 1999, 2000) indicated that species of conservation concern are distributed unevenly among habitats and landforms. Whereas lowland habitats in southern Mexico are rich in species, they are poor in endemic forms, and endemic, rare and range-restricted species (Peterson and Watson 1998) are concentrated in middle-to-high elevation habitats (Peterson et al. 1993).

Habitats richest in restricted-range species are generally the montane habitats of pine, pine-oak, and cloud forests, although the dry lowlands of the southern 
fringe of the Chimalapas hold a surprising number of narrowly endemic species. Because the Chimalapas contains complete lowland-to-montane gradients, it is likely to hold both habitats with high species richness (lowlands) and rich in endemic and restricted-range species (mountains). We compared three broad areas within the Chimalapas (Atlantic lowlands with humid rainforest, mountains and Pacific lowlands with dry tropical forest); here again, the massive richness of species in the Atlantic lowlands is clear. Comparing richness of species endemic to Mexico, the Atlantic lowlands are endemism-poor (less than 2\% endemic), and montane areas richer (3.7\% endemic). However, the Pacific lowlands are much richer, with $7.5 \%$ of species endemic to Mexico, contra our previous results (Peterson et al. 1993).

Having considered broad patterns across the Chimalapas, an important consideration is the degree to which the three areas are homogeneous faunistically. Unfortunately, data relevant to this issue are insufficient. The two montane sites that have been surveyed carefully (Cerro Baúl, Cerro Salomón) have similar avifaunas. These two sites, however, lie in close proximity, so montane comparisons will remain incomplete until more disparate montane areas are surveyed (e.g. Cerro Azul, Sierra de Tres Picos).

In the Atlantic lowlands, Chalchijapa and San Isidro La Gringa appear similar avifaunistically at first glance. However, differences exist: for example, the vocal and easily identified Rufous Piha Lipaugus unirufus was detected frequently at Chalchijapa, yet the same investigators in the same season failed to encounter the species a single time at La Gringa. Similarly, several species were detected at La Gringa that were not detected at Chalchijapa: Speckled Mourner Laniocera rufescens and Keel-billed Motmot were particularly interesting examples.

\section{Discussion}

The importance of the Chimalapas as a protected natural area is indubitable. The area holds a rich store of biological diversity, including numerous endemic species of small vertebrates and plants, as well as healthy populations of many species otherwise in grave danger of extinction. More generally, the Chimalapas greatly outrank other potential conservation areas in Oaxaca when compared using indices of vulnerability to extinction (Peterson et al. unpubl. data). The area holds immense lowland rainforests and cloud forests that certainly rank among the largest and best preserved in all of Mesoamerica. Moreover, these habitats are arranged in a lowland-to-highland continuum, with entire watersheds preserved more or less intact.

The fauna of the Chimalapas remains poorly known, in spite of the new information presented herein. Surveys by our colleagues in 1995 recorded 188 butterfly species, 20 amphibians, 48 reptiles and 40 mammals, but this information remains to be integrated with the broader spectrum of existing information from natural history collections. Knowledge of a broader spectrum of biodiversity in the region is close to nil. Moreover, for all taxa, including birds, inventories at several remote sites are critical to a complete understanding of the region: Cerro Azul; the rainforest north and east of Santa María Chimalapa, including 
the southern slopes of the Sierra de Tres Picos; the higher parts of the Sierra de Tres Picos; dry forest in the municipio de San Miguel Chimalapa; and the Sierra Espinazo del Diablo.

The Chimalapas presents a unique opportunity for conservation in Mexico, holding some of the very best opportunities for truly effective protection of biodiversity. However, it also presents several very serious challenges. The Reserva Ecológica Campesina de Los Chimalapas was declared by the local people in the early 1990s, and has seen some support and recognition officially and by the conservation community. However, much of the future success of the Reserva will depend on effective solutions to problems of land tenancy and the integrity of the borders of the state of Oaxaca. This challenge holds the key, either to an exciting future of a viable reserve, or an extremely pessimistic forecast that would spell the end of the Chimalapas region as a natural area.

\section{Acknowledgements}

We thank our many field companions, including Armando Luis, Jorge Meave, Livia León, Marco Antonio Romero, Armando Rincón, Adriana Osnaya, Carlos Ruiz Jiménez, Sergio Mendoza, Rodolfo Noriega, Octavio Rojas, Esperanza Álvarez, Samuel López, Luis Canseco, Edmundo Pérez, Ubaldo Melo, José García, José Luis Salinas, and Mauro Vences. Critical logistical support was provided by Maderas del Pueblo del Sureste A. C., as well as by local people and governments. Raúl Jiménez Rosenberg (CONABIO) and María del Coro Arizmendi (CIPAMEX) provided digital versions of maps. Thomas Schulenberg, Seb Buckton, Alejandro Gordillo, and an anonymous reviewer provided useful comments on the manuscript. The following scientific collections kindly made data and specimens available to us for study and use in this study: American Museum of Natural History; Academy of Natural Sciences of Philadelphia; Bell Museum of Natural History; British Museum (Natural History); California Academy of Sciences; Carnegie Museum of Natural History; Canadian Museum of Nature; Denver Museum of Natural History; Delaware Museum of Natural History; Fort Hays State College; Field Museum of Natural History; Iowa State University; University of Kansas; Los Angeles County Museum of Natural History; Natuurhistorische Museum; Louisiana State University Museum of Zoology; Museum of Comparative Zoology, Harvard University; Moore Laboratory of Zoology, Occidental College; Museum Nationale D'histoire Naturelle; Museum of Vertebrate Zoology, Berkeley; Museo de Zoología, Facultad de Ciencias, Universidad Nacional Autónoma de México; University of Nebraska; Royal Ontario Museum; San Diego Natural History Museum; Southwestern College; Texas Cooperative Wildlife Collections; University of Arizona; University of British Columbia Museum of Zoology; University of California Los Angeles; University of California Berkely; Universidad Michoacana de San Nicolás de Hidalgo; United States National Museum of Natural History; Western Foundation of Vertebrate Zoology; and Peabody Museum, Yale University. Financial support was obtained from the National Science Foundation; Conservation International; Secretaría de Medio Ambiente, Recursos Naturales y Pesca (SEMARNAP); Consejo Nacional de Ciencia y Tecnología (CONACyT); Dirección General de Asuntos del Personal Académico (DGAPA-UNAM); British Council (México); and the Comisión Nacional para el Conocimiento y Uso de la Biodiversidad (CONABIO). 


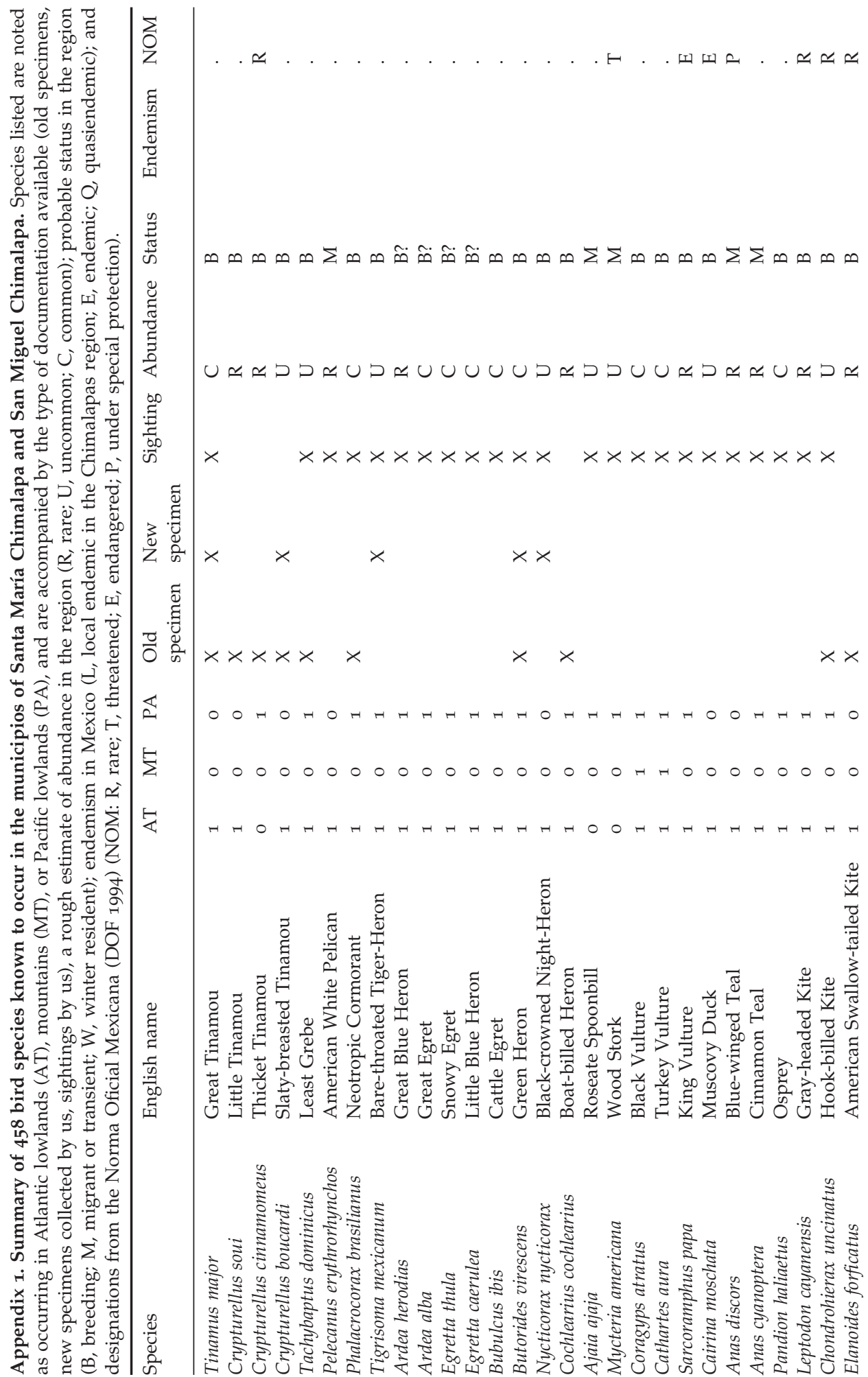




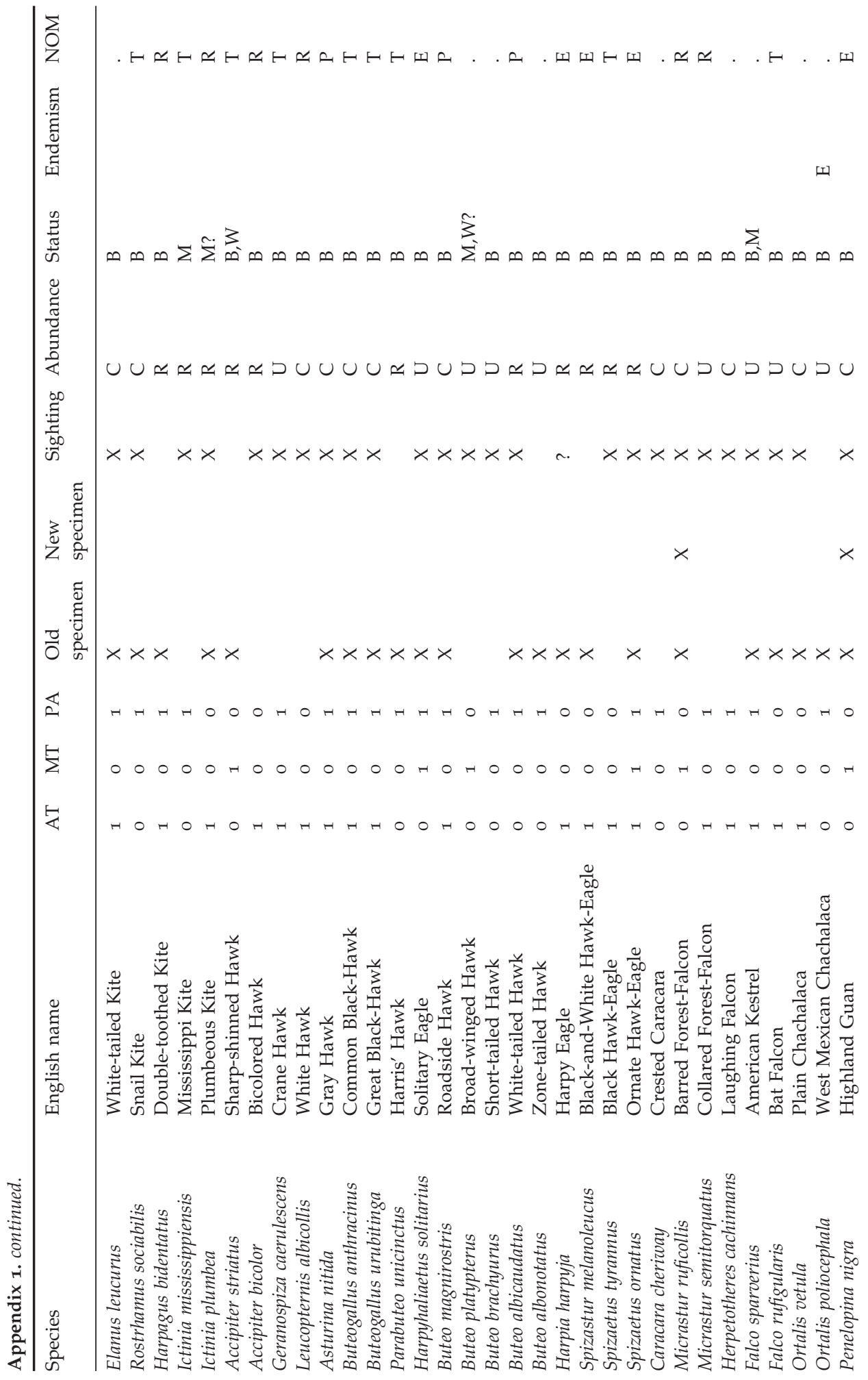




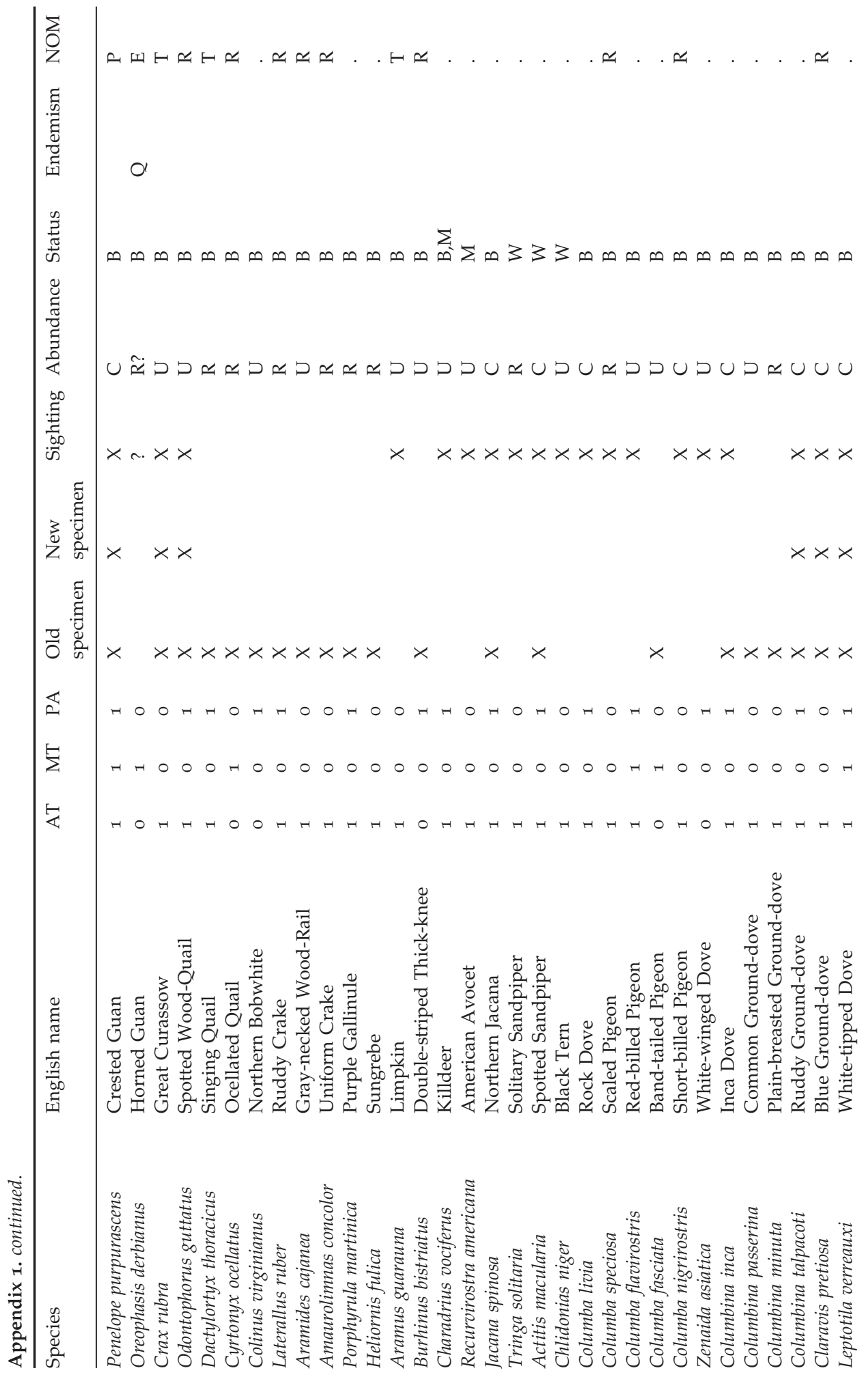




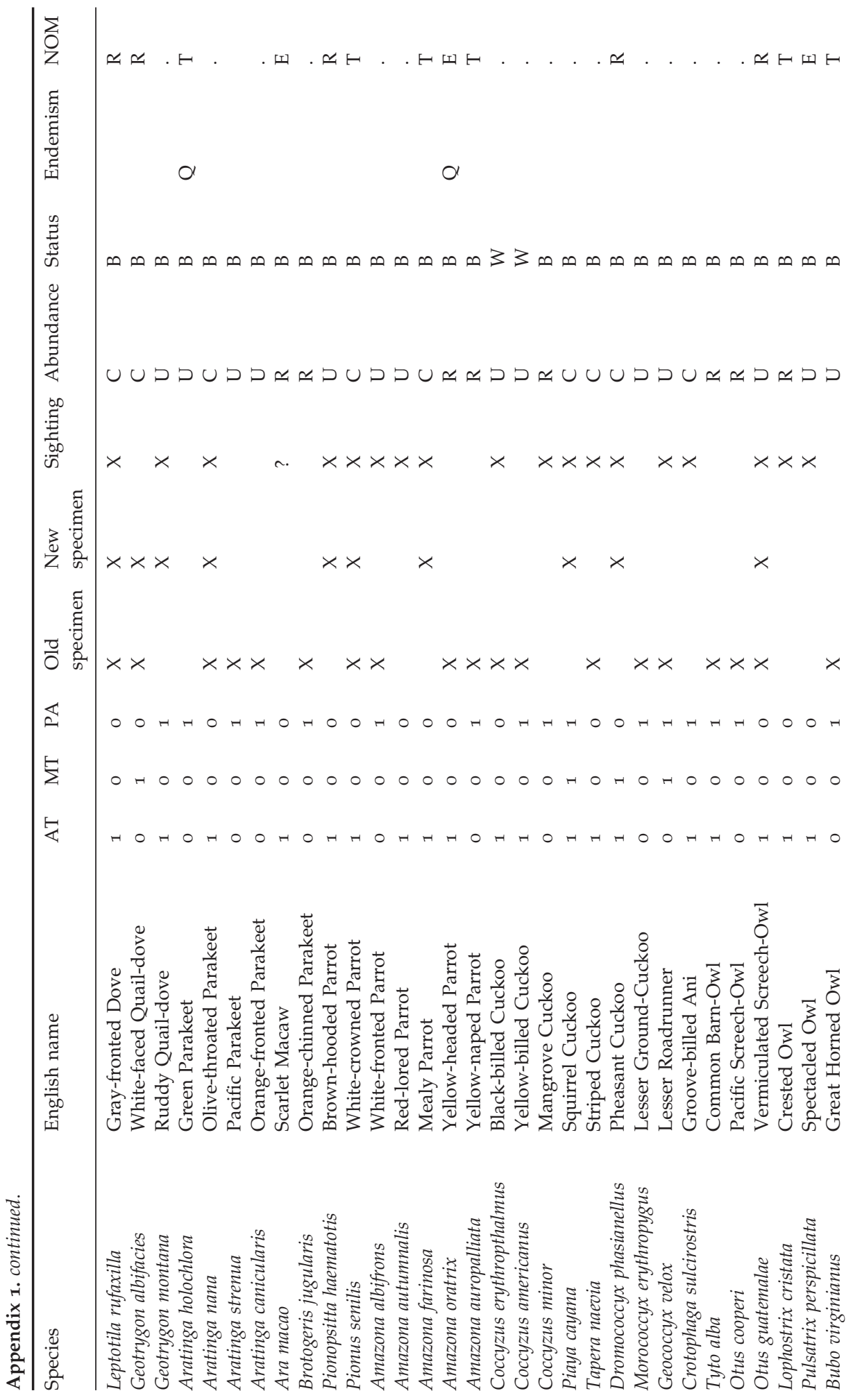




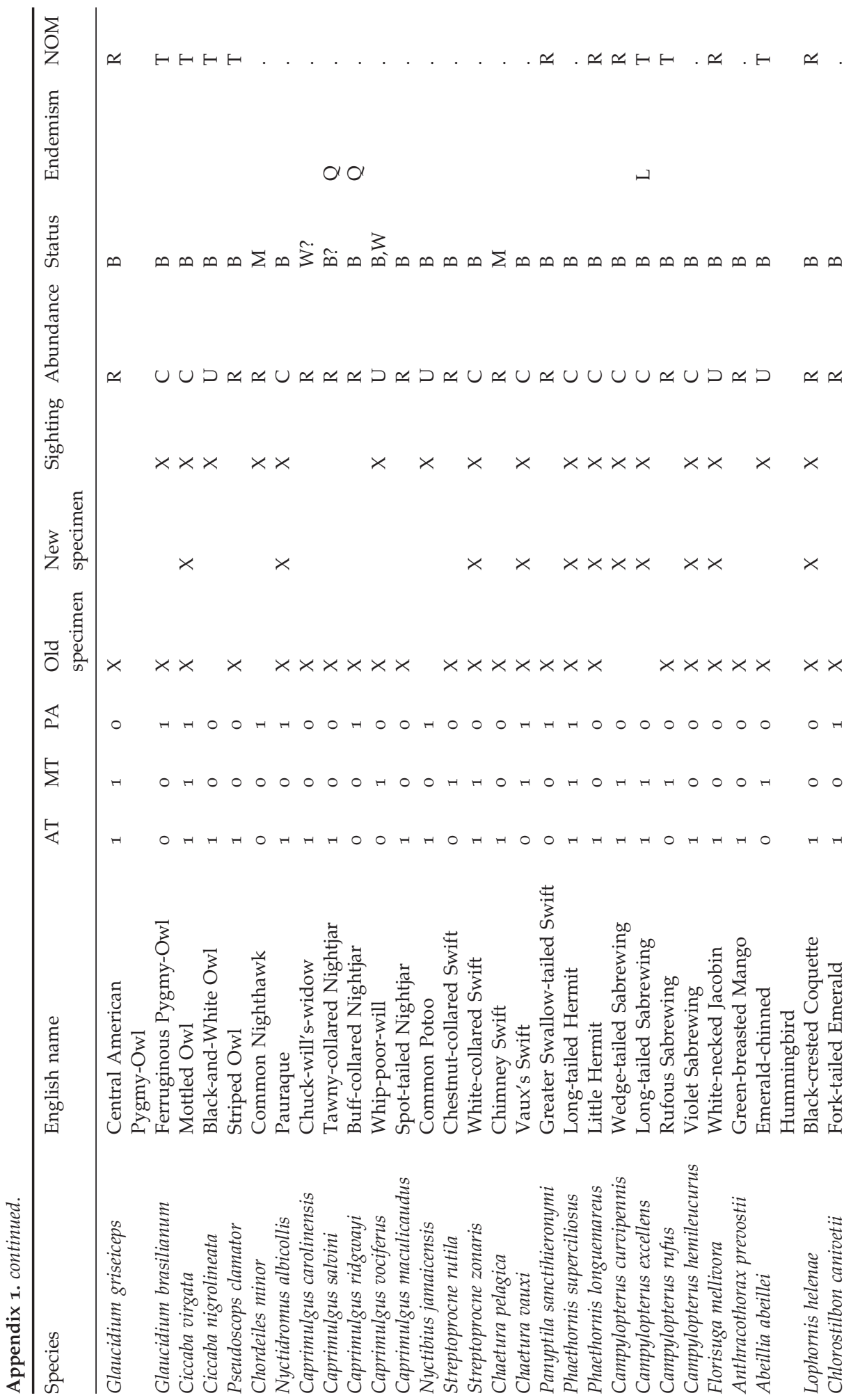




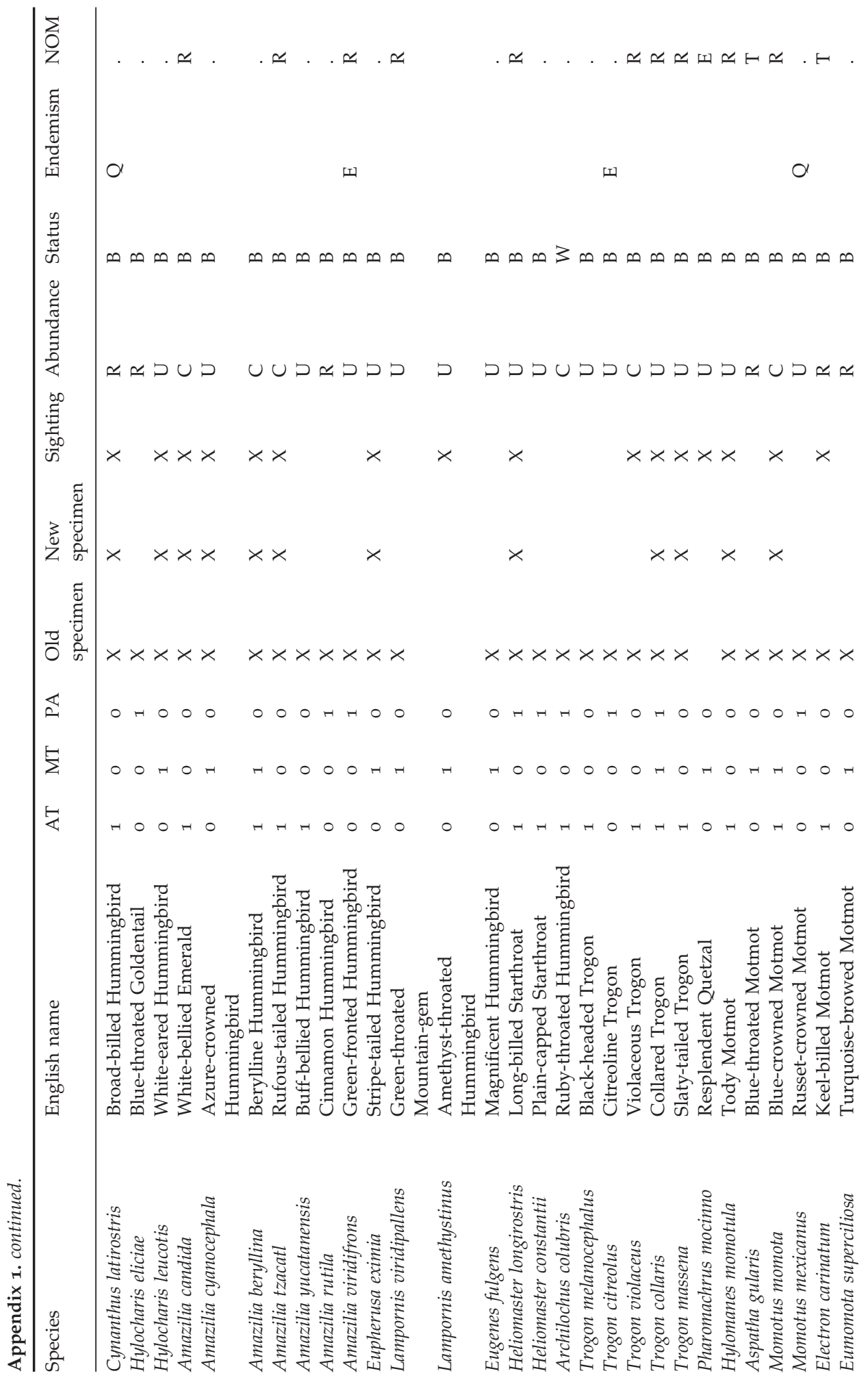




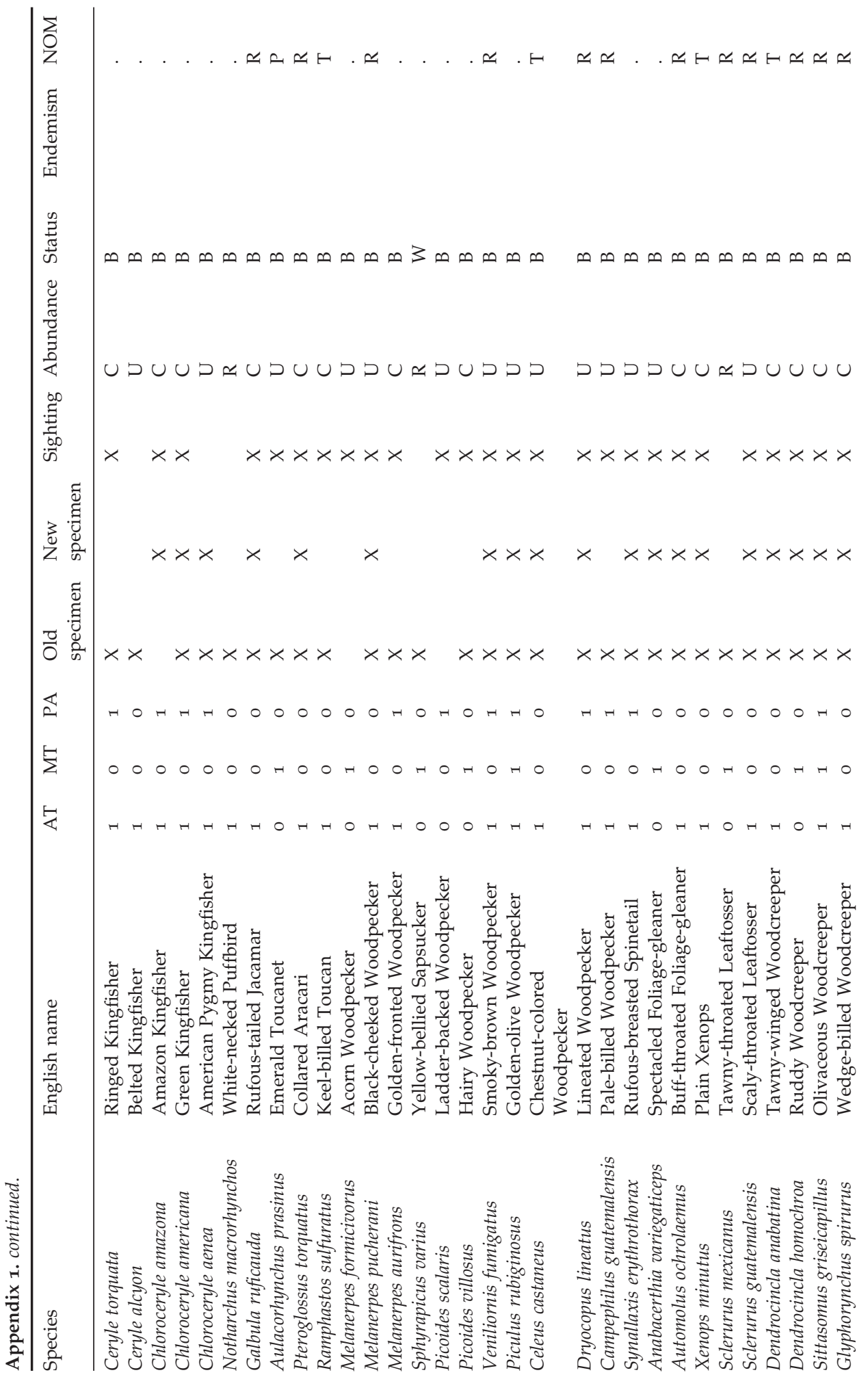




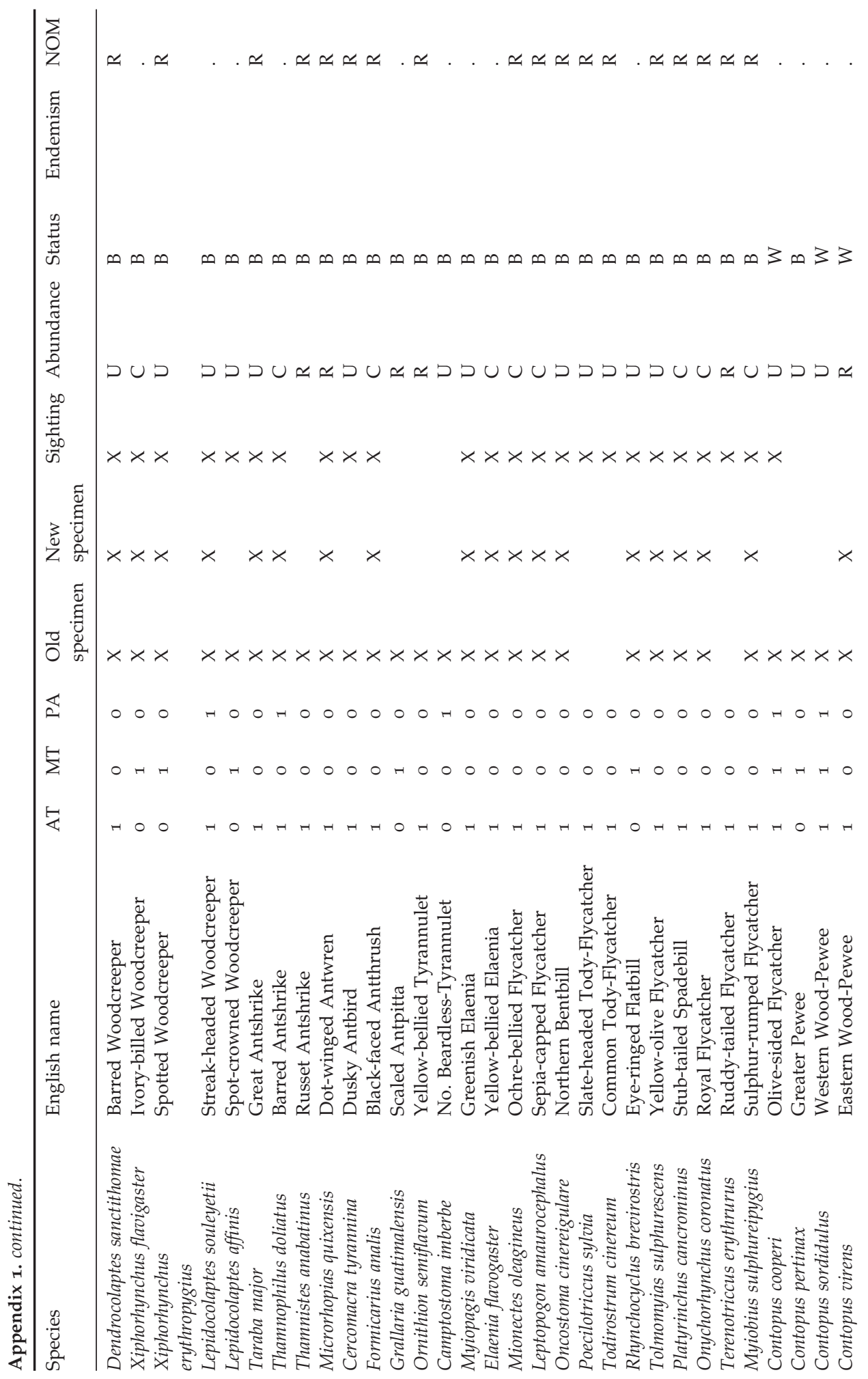




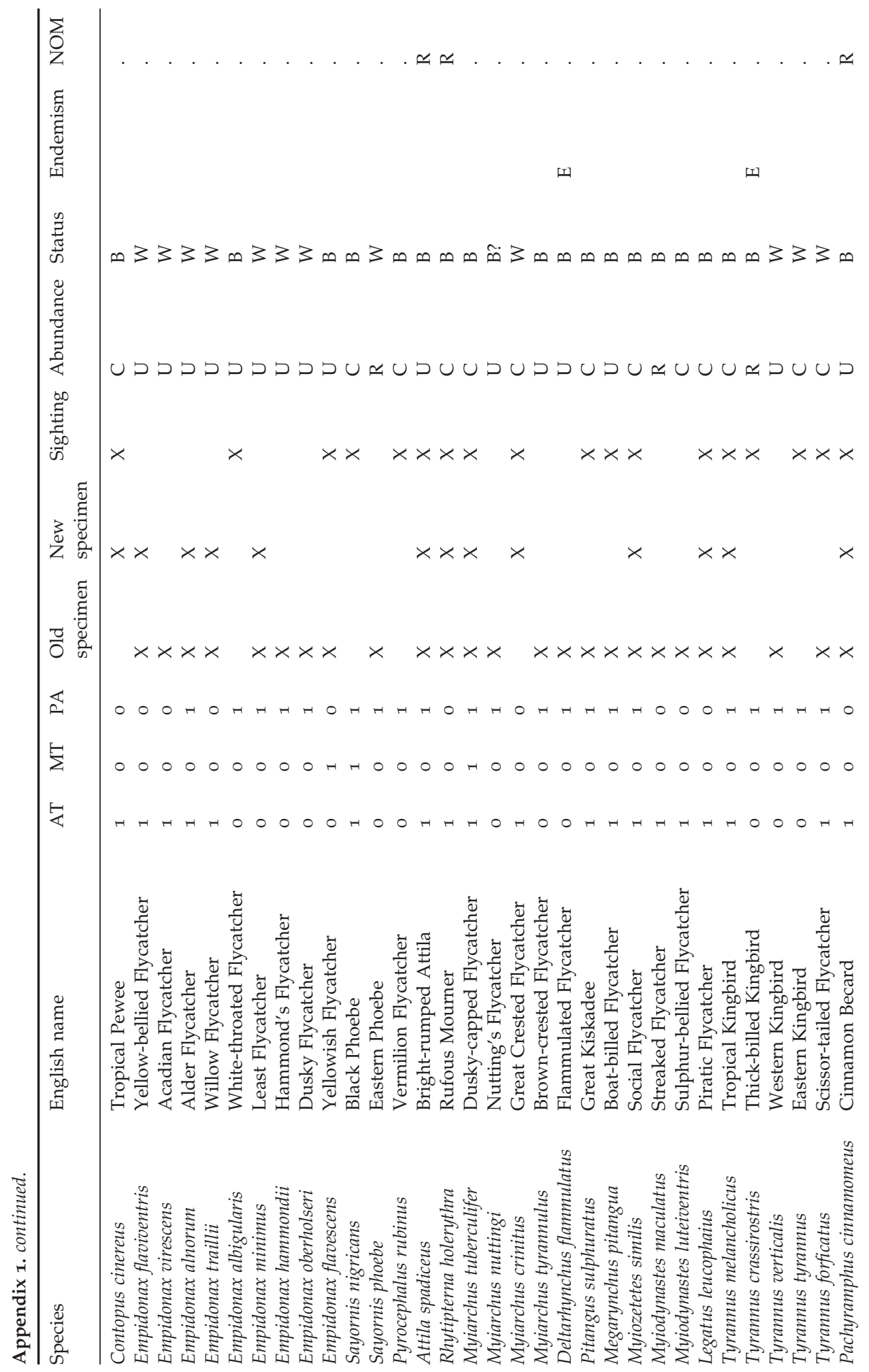




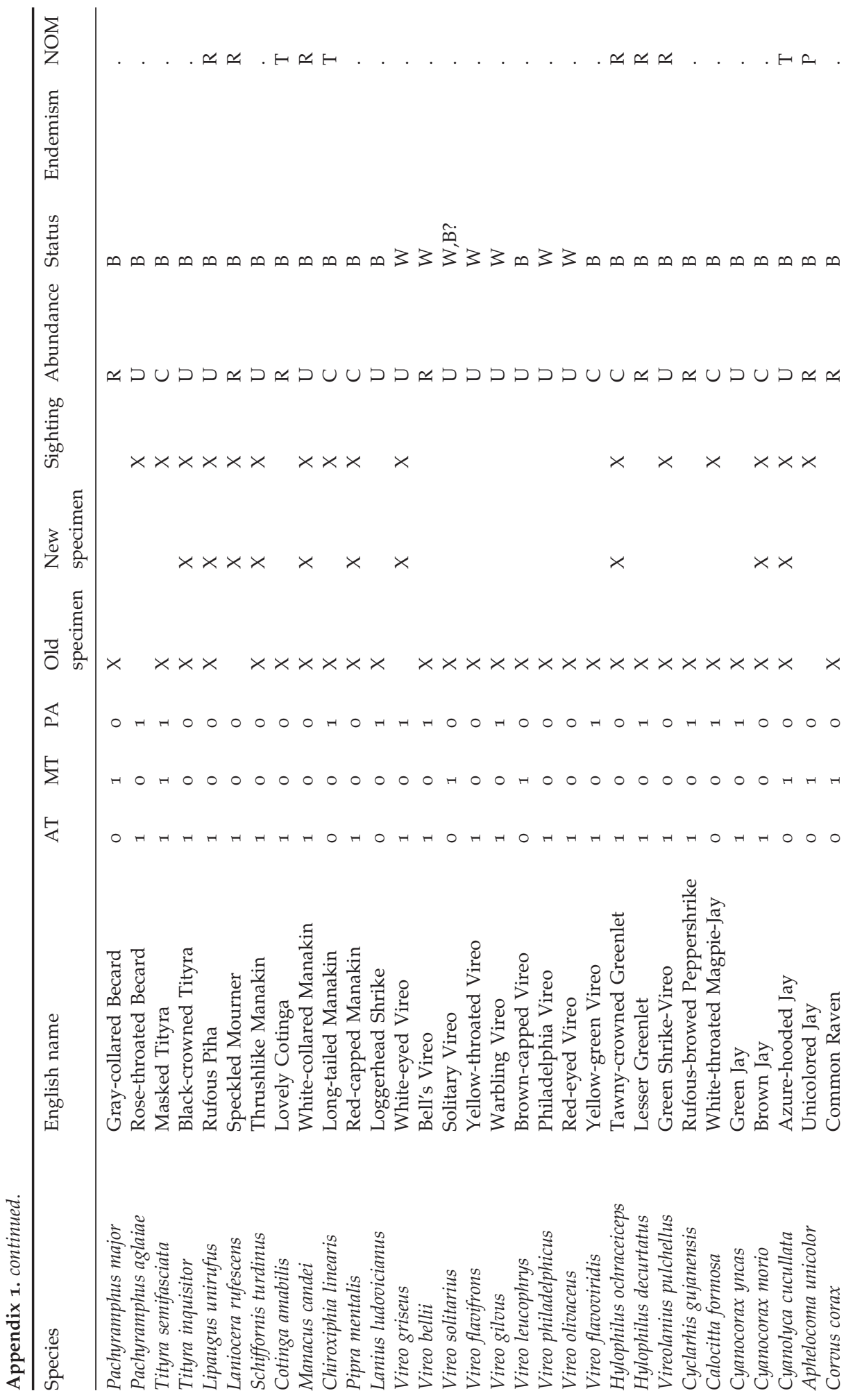




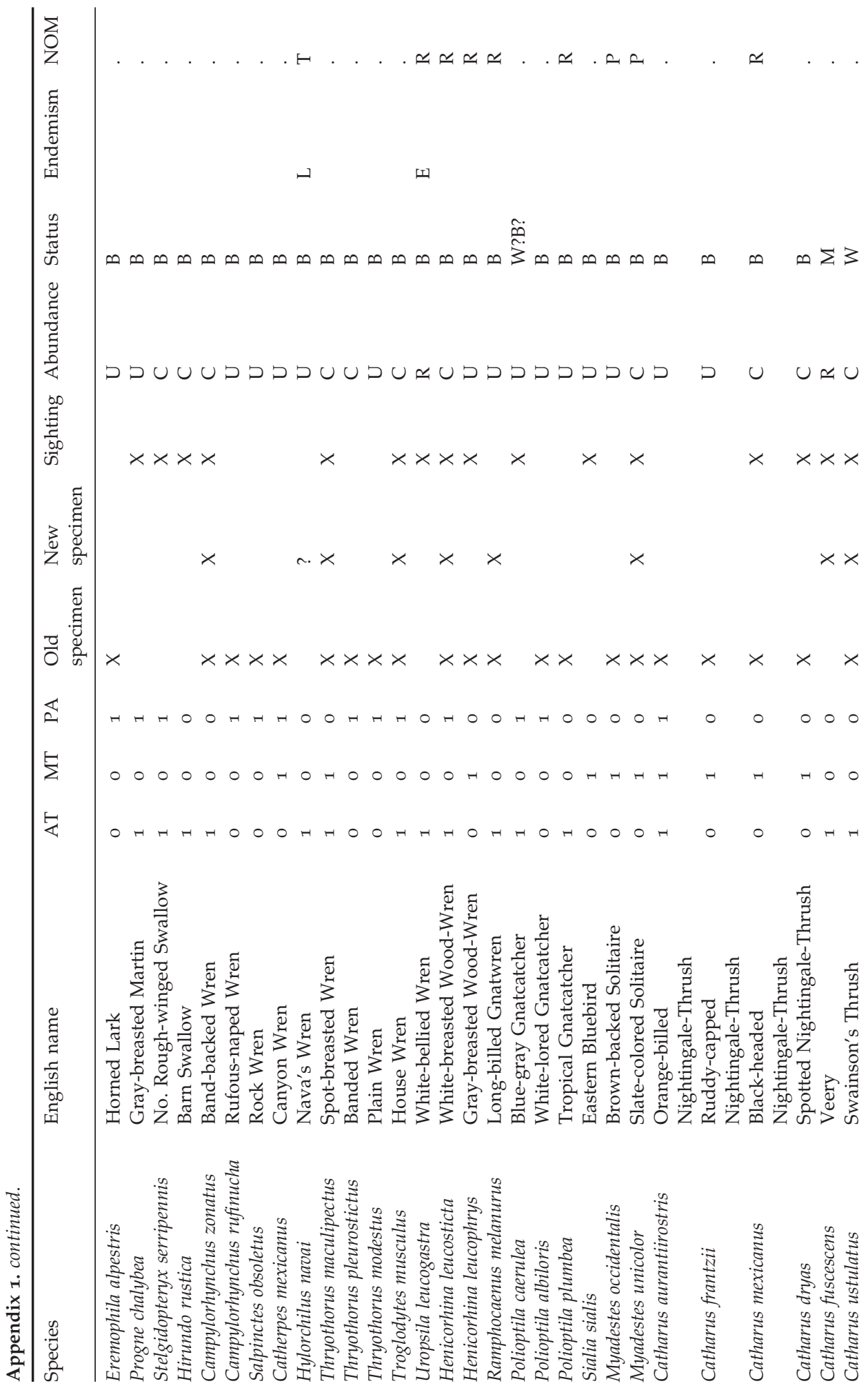




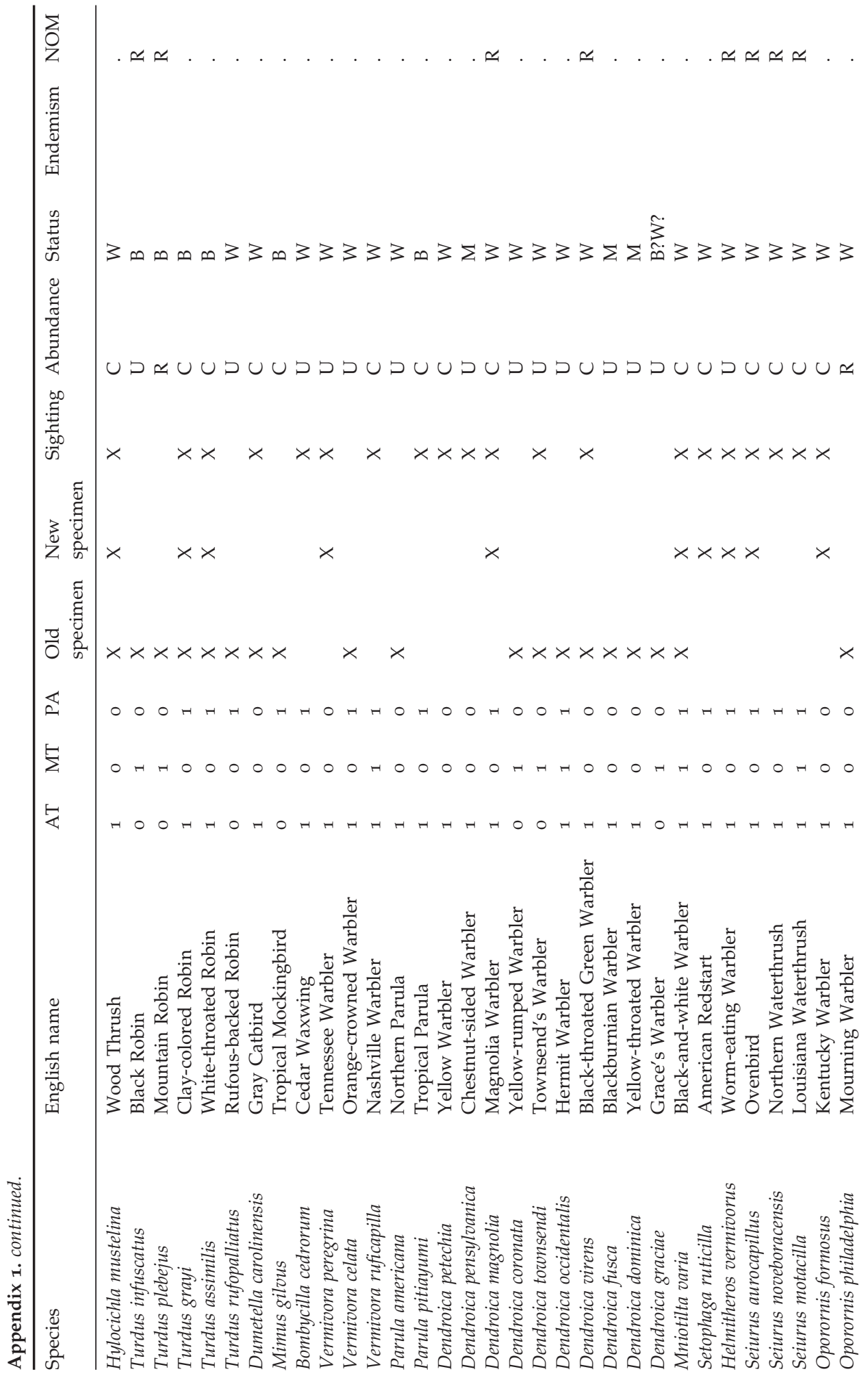




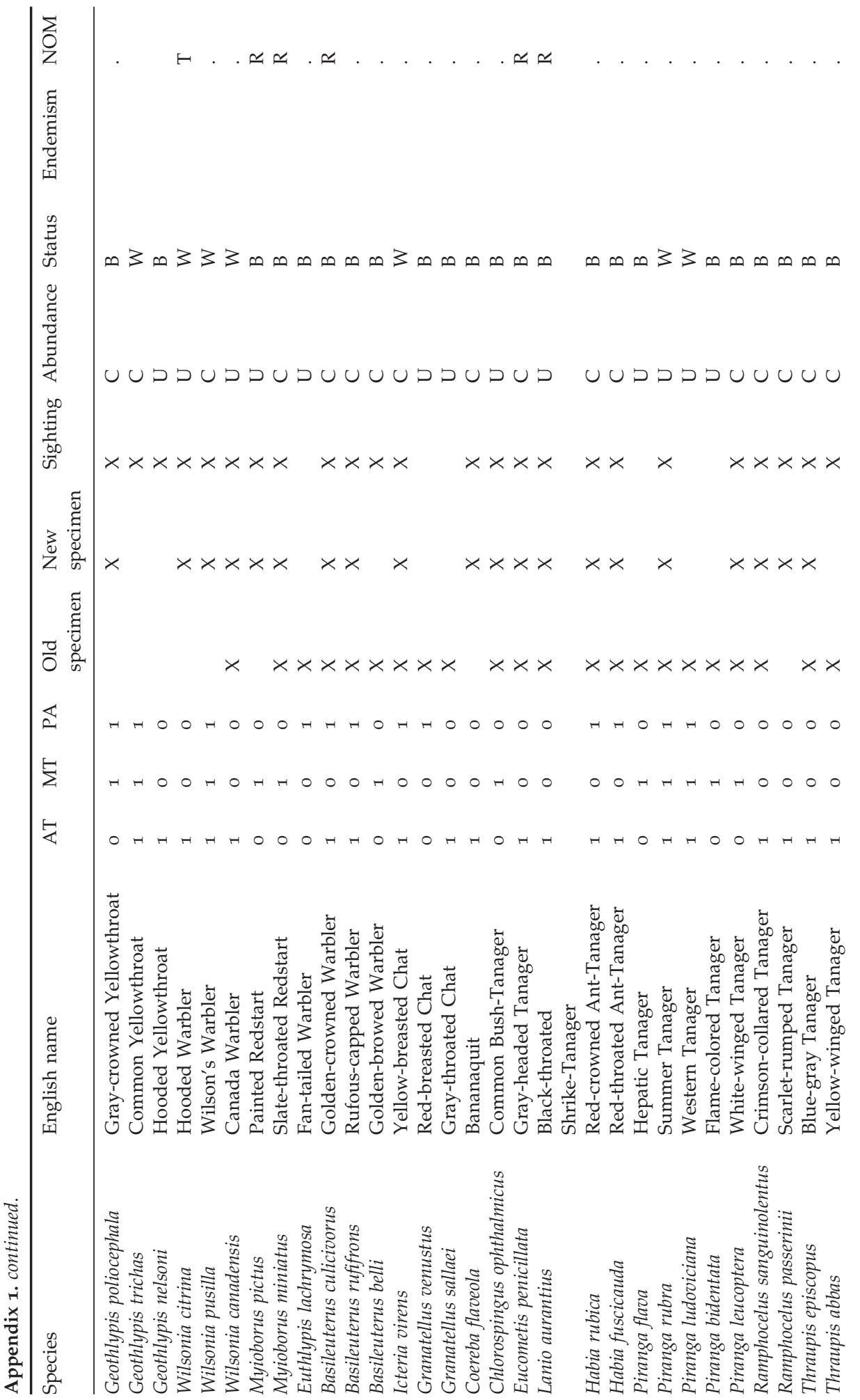




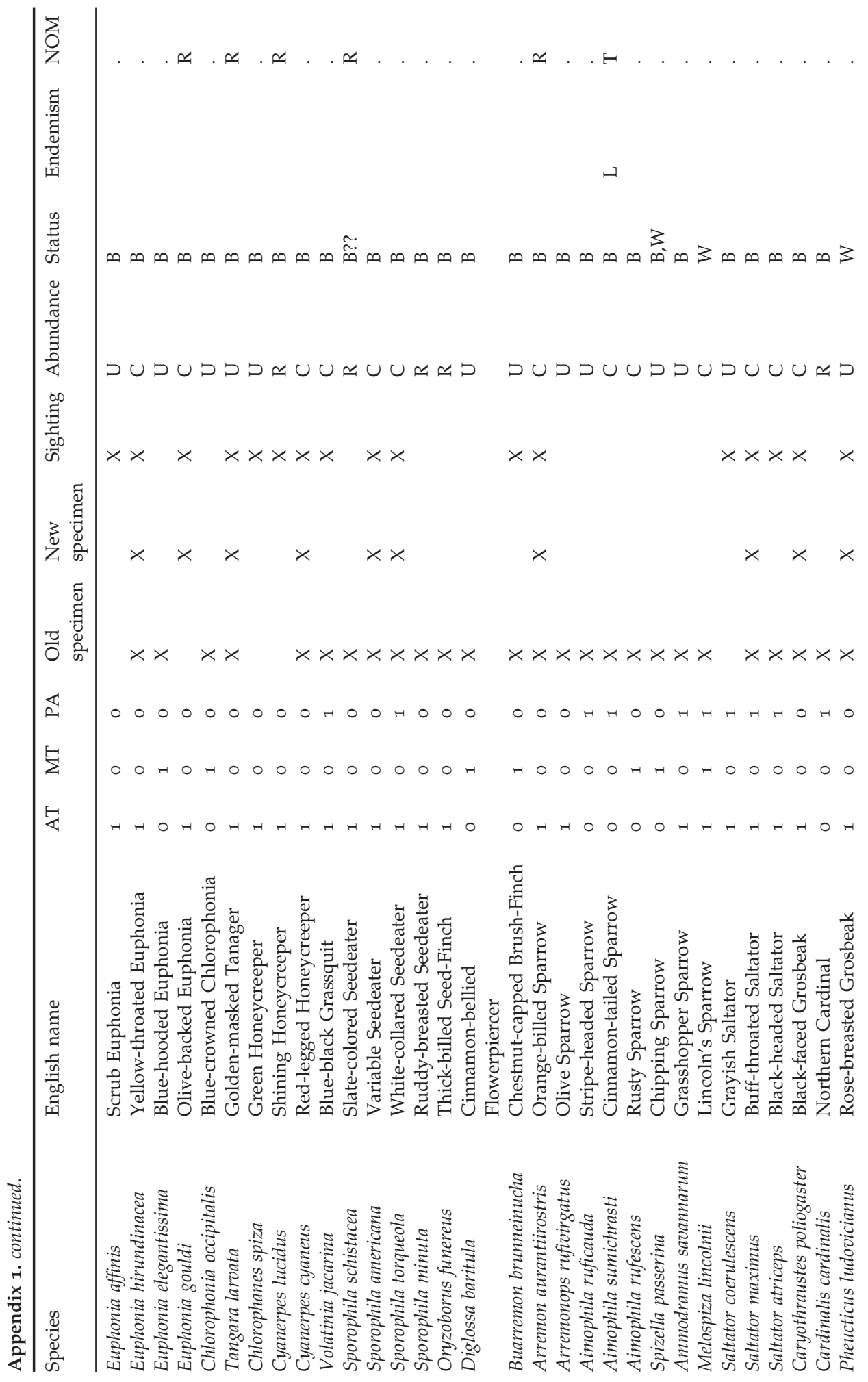


The Chimalapas Region, Oaxaco, Mexico

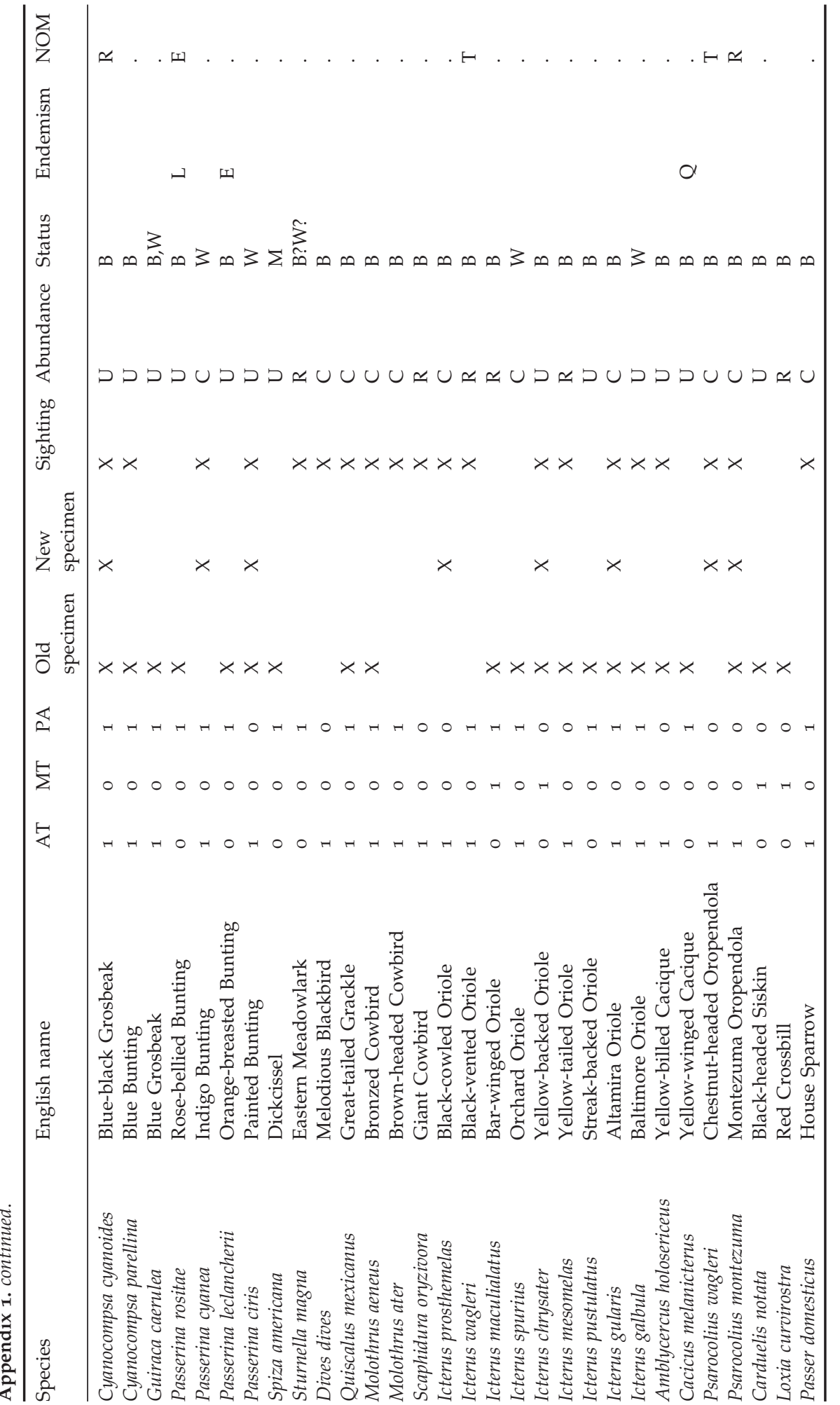




\section{References}

A.O.U. (1998) Check-list of North American birds. Eighth edition. Washington, D.C.: American Ornithologists' Union.

Arizmendi, M. C. and Márquez, L. (2000) Áreas de importancia para la conservación de las aves de México. México: CIPAMEX-CONABIO-FOMEX.

Arriaga-Cabrera, L., Espinoza, J. M., Águilar, C., Martínez, E., Gómez, L. and Loa, E. (2000) Regiones terrestres prioritarias de México. México: Comisión Nacional para el Conocimiento y Uso de la Biodiversidad (CONABIO).

Atkinson, P. W., Whittingham, M. J., de Silva Garza, H., Kent, A. M. and Maier, R. T. (1993) Notes on the ecology, conservation and taxonomic status of Hylorchilus wrens. Bird Conserv. Internatn. 3: 75-85.

Binford, L. C. (1989) A distributional survey of the birds of the Mexican state of Oaxaca. Orn. Monogr. 43: 1-405.

BirdLife International (2000) Threatened birds of the world. Barcelona: Lynx Editions.

DOF (1994) Norma oficial mexicana NOM-ECOL-059-1994. Diario Oficial de la Federación, 16 de mayo de 1994.

Escalante-Pliego, P., and Peterson, A. T. (1994) Status of the Harpy Eagle (Harpia harpyja) in Oaxaca. Euphonia 2: 95-97.

Escalante-Pliego, P., Navarro-Siguenza, A. G. and Peterson, A. T. (1993) A geographic, historical, and ecological analysis of avian diversity in Mexico. Pp. 281-307 in T. P. Ramamoorthy, R. Bye, A. Lot and J. Fa, eds. Biological diversity of Mexico: origins and distribution. New York: Oxford University Press.

Hernández-Baños, B. E., Peterson, A. T., Navarro-Sigüenza, A. G. and Escalante-Pliego, P. (1995) Bird faunas of the humid montane forests of Mesoamerica: biogeographic patterns and conservation priorities. Bird Conserv. Internatn. 5: 251-277.

Maderas del Pueblo del Sureste A. C. (1995) Regiones y localidades en los Chimalapas. Map modified from INEGI (1993) Cartas Topográficas Escala 1:250 000, 1981-82. México.

Miller, B. W. and Miller, C. M. (1996) New information on the status and distribution of Keel-billed Motmot in Belize, Central America. Cotinga 6: 61-64.

Peterson, A. T. and Navarro-Sigüenza, A. G. (1999) Species concepts and setting conservation priorities: a Mexican case study. In Proceedings XXII International Ornithological Congress, Durban, South Africa.

Peterson A. T. and Navarro-Sigüenza, A. G. (2000) Western Mexico: A significant center of avian endemism and challenge for conservation action. Cotinga 14: 42-46.

Peterson, A. T. and Watson, D. M. (1998) Problems with areal definitions of endemism: The effects of spatial scaling. Divers. Distrib. 4: 189-194.

Peterson, A. T., Flores V., O. A., León P., L. S., Llorente B., J. E., Luis M., M. A., NavarroSigüenza, A. G., Torres Ch., M. G. and Vargas F., I. (1993) Conservation priorities in northern Middle America: Moving up in the world. Biodiv. Lett. 1: 33-38.

Peterson, A. T., Escalona-Segura, G. and Griffith, J. A. (1998a) The birds of northern Central America: a preliminary distributional analysis. Wilson Bull. 110: 534-543.

Peterson, A. T., Navarro-Sigüenza, A. G. and Benítez-Díaz, H. (1998b) The need for continued scientific collecting: a geographic analysis of Mexican bird specimens. Ibis 140: 288-294.

Ramamoorthy, T. P., Bye, R., Fa, J. and Lot, A., eds. (1993) Biological diversity of Mexico: origins and distribution. New York: Oxford University Press.

Rowley, J. S. (1984) Breeding records of land birds in Oaxaca, Mexico. Proc. West. Foundation Vertebr. Zool. 2: 73-224.

Wendt, T. (1989) Las selvas de Uxpanapa, Veracruz-Oaxaca: evidencia de refugios florísticos cenozóicos. Anales Instituto de Biología UNAM, Serie Botánica 58: 29-54.

Wendt, T. (1993) Composition, floristic affinities, and origins of the canopy tree flora of 
the Mexican Atlantic slope rainforests. Pp. 595-68o, In: T. P. Ramamoorthy, R. Bye, A. Lot and J. Fa, eds. Biological diversity of Mexico: origins and distribution. New York: Oxford University Press.

Wilson, E. O., ed. (1988) Biodiversity. Washington, D.C.: National Academy Press.

\section{A. TOWNSEND PETERSON}

Natural History Museum, The University of Kansas, Lawrence, Kansas 66045, U.S.A.

ADOLFO G. NAVARRO-SIGÜENZA, BLANCA E. HERNÁNDEZ-BAÑOS, FANNY REBÓN-GALLARDO, EMIR RODRÍGUEZ-AYALA, ELSA M. FIGUEROA-ESQUIVEL

Museo de Zoología, Facultad de Ciencias, Universidad Nacional Autónoma de México, México.

\section{GRISELDA ESCALONA-SEGURA}

Museo de Zoología, Facultad de Ciencias, Universidad Nacional Autónoma de México, México and Colegio de la Frontera Sur (ECOSUR) Unidad Campeche, Campeche, Mexico.

\section{LEONARDO CABRERA-GARCÍA}

Museo de Zoología, Facultad de Ciencias, Universidad Nacional Autónoma de México, México and Laboratorio de Biogeografía, Facultad de Ciencias, Universidad Nacional Autónoma de México, Ciudad Universitaria, México.

Received 4 April 2001; revision accepted 16 January 2003 
